\title{
Space-time asymmetries: Russian 6 'in(to)' and the North Slavic Temporal Adverbial Continuum
}

\begin{abstract}
This article presents a corpus-based investigation of temporal adverbials with special focus on Russian 8 'in(to)' and its cognates in North Slavic (Belarusian, Ukrainian, Polish and Czech). We advance the Constraint Hypothesis, according to which case government is more restricted in the domain of time than in the domain of space. This hypothesis receives support from the five languages under scrutiny insofar as the distribution of the accusative vs. locative after 8 and its cognates is contrastive in the domain of space, but complementary in temporal adverbials. On this basis, we argue that the relationship between space and time is asymmetrical. Although all five languages display space-time asymmetries, we show that they have different systems of temporal adverbials, including a number of constructions with prepositions or bare cases. In order to capture the differences we propose a North Slavic Temporal Adverbial Continuum, which is corroborated by a thorough statistical investigation of data from the ParaSol corpus.
\end{abstract}

Аннотация: В статье представлено корпусное исследование обстоятельств времени в северных славянских языках (русском, белорусском, украинском, польском и чешском). В фокусе внимания данной работы русские обстоятельства времени с предлогом $в$ и их соответствия в северных славянских языках. Мы предлагаем Гипотезу Ограничения, согласно которой падежное управление менее свободно в сфере выражения временных отношений, чем пространственных. Эта гипотеза находит подтверждение на материале пяти славянских языков: распределение винительного и предложного падежей после предлога в (и его аналогов в других славянских языках) является контрастным в пространственных, и дополнительным во временных конструкциях. На этом основании мы утверждаем, что отношения между выражением пространства и времени в языке являются асимметричными. Такая пространственно-временная асимметричность наблюдается во всех пяти исследуемых языках, однако системы обстоятельств времени в этих языка различны. В функции обстоятельств времени используются как предложно-падежные конструкции, так и падежные формы без предлогов. Разнообразие в способах оформления обстоятельств времени в северных славянских языках позволяет постулировать Северно-славянский Континуум Обстоятельств Времени. Выдвинутые в работе гипотезы подтверждаются статистическим анализом данных из корпуса ParaSol.

Keywords: temporal adverbials, space-time asymmetries, statistical analysis of language data, East Slavic, West Slavic

\section{Overview}

The relationship between time and space has received considerable attention in cognitive linguistics as a prime example of a metaphorical relationship between 
a concrete source domain (space) and an abstract target domain (time) (cf. e.g. Haspelmath 1997). The objective of the present article is to shed light on the relationship between time and space in language through a corpus-based study of temporal adverbials with Russian $\theta$ 'in(to)' and its cognates in North Slavic. We limit ourselves to North Slavic (i.e. East and West Slavic), since these languages represent a geographical continuum, and therefore lend themselves to comparative analysis. Since the starting point of our comparison is Russian, we included both Belarusian and Ukrainian in our language sample. As representatives for the West Slavic languages we chose Czech and Polish.

Our contribution is twofold. First, we demonstrate that the relationship between space and time is asymmetric, in the sense that case government is more constrained in time than in space. While in space the distribution of the accusative and locative cases after 8 'in(to)' is contrastive, in time we observe complementary distribution. Our second contribution pertains to the differences among the North Slavic languages.

Although we show that space-time asymmetries are observed in all the languages under scrutiny, we show that the locative has a wider distribution in the west than in the east. In order to capture this generalization, we propose a North Slavic Temporal Adverbial Continuum.

Our argument is structured as follows. After a brief presentation of our hypothesis and data in section 2, we explore the Russian data in section 3, which are then compared to Belarusian, Ukrainian, Polish and Czech in sections 4 through 7. Section 8 offers a statistical analysis of corpus data, corroborating the proposed North Slavic Temporal Adverbial Continuum. The contribution of the article is summarized in section 9.

\section{Hypothesis and data}

Lakoff $(1993,203)$ defines "metaphor" as "a cross-domain mapping in the conceptual system". Time and space are examples of domains, and the TIME IS SPACE metaphor has been proposed in order to accommodate the fact that languages recruit spatial concepts to represent time. While the English preposition in prototypically describes inclusion in a three-dimensional space (e.g. in the basement), in also combines with temporal nouns (cf. in November). Arguably, we are dealing with a metaphorical mapping, whereby a time span (November) is described and conceptualized as a three-dimensional space. However, the domains of time and space are not entirely parallel, as shown by the following examples from Fauconnier and Turner $(2008,55)$ :

(1) Three hours went by, and then he had dinner.

(2) *Three feet went by, and he was at the door.

As shown in (1), measurements of time such as hour combine with verbs of motion, but time is not a mirror image of space in this respect, since measurements of spatial distance like foot do not permit the parallel construction in (2). We suggest referring to examples of this sort as "space-time 
asymmetries", although Fauconnier and Turner (2008) do not use this term. ${ }^{1}$ On the basis of space-time asymmetries like the ones in (1) and (2), Fauconnier and Turner (2008) argue that time is not best conceived of as a single target domain in a metaphor from the domain of space to the domain of time. Rather, they argue, time is an emergent property in a complex network of blended mental spaces (cf. Dahl to appear for a similar idea).

A discussion of the relative merits of the traditional theory of conceptual metaphor (Lakoff and Johnson 1980) and Fauconnier and Turner's (2002) theory of conceptual integration ("blending") is beyond the scope of the present article. Instead we offer an empirical investigation of space-time asymmetries, focusing on case government in temporal adverbials with the Russian preposition $B$ 'in(to)' and its cognates in other Slavic languages. These prepositions govern either the accusative or locative cases (cf. Russian $B$ понедельник 'on Monday' in the accusative vs. в январе 'in January' in the locative). Both cases are attested although the relevant adverbials are of the same type. Both в понедельник and в январе specify a time span that overlaps with an event. In the terminology of Klein $(1994,149 ; 2009,65)$ such adverbials are a subtype of "temporal adverbials of position".

The question we address in the present study is whether case government in temporal adverbials parallels case government in spatial constructions. We argue that the answer is "no", and advance the following hypothesis:

(3) The Constraint Hypothesis: Case government is more constrained in the domain of time than in the domain of space.

A prediction from this hypothesis is that some of the case oppositions from spatial constructions are not maintained in temporal constructions. In the following, we will see that this prediction is borne out by facts from corpus data. Although case government is different in the languages under scrutiny (Russian, Belarusian, Ukrainian, Polish and Czech), which enables us to propose a North Slavic Temporal Adverbial Continuum, all the languages display space-time asymmetries. While in spatial constructions the accusative and locative cases are used contrastively, the opposition is neutralized in the domain of time, where the two cases are in complementary distribution.

In order to test the Constraint Hypothesis and the hypothesis about the North Slavic Temporal Adverbial Continuum we set up a database from the ParaSol corpus, a parallel corpus with translations of literary texts in all Slavic as well as a number of other languages. ${ }^{2}$ Our data come from four literary texts, for which the corpus contains data for all five languages under scrutiny: Das Parfüm

\footnotetext{
${ }^{1}$ Our use of the term "asymmetry" is in line with the geometrical sense of the term. Simply put, in geometry "symmetry" is when one shape becomes exactly like another if you flip, slide or turn it, while "asymmetry" describes a situation where this is not the case. We use "asymmetry" about situations where linguistic constructions for time are not a mirror image of spatial constructions (cf. Nesset 2011). Similar differences between space and time are explored in Kuznetsova, Plungian and Rakhilina (this volume) and Plungian and Rakhilina (this volume).

2 The ParaSol corpus is available at www.parasol.unibe.ch. Unless otherwise indicated, numbered examples in this study are from the ParaSol corpus. For the convenience of our readers, we provide the name of the author in parentheses after cited examples from our database.
} 
(Süskind), Solaris (Lem), Kak zakaljalas' stal' (N. Ostrovskij) and Master $i$ Margarita (Bulgakov). In other words, our database includes texts by two Russian writers, one Polish and one German. Ideally, we would have liked to include texts originally written in all the languages under comparison, as well as more texts originally written in non-Slavic languages. However, further texts were not available in the ParaSol corpus. The data were gathered as follows. We extracted all Russian examples with the preposition $v(o)$ and their equivalents in the four other languages. Afterwards, examples with non-temporal uses of $v(o)$ were removed manually, and all the remaining examples were tagged for preposition, case and temporal noun. The resulting database comprises 271 Russian examples and their equivalents in the other languages.

\section{Contemporary Standard Russian: two constraints}

In this section we explore the distribution of the accusative and locative cases governed by the preposition 8 'in' in Contemporary Standard Russian, which will serve as the standard of comparison in our North Slavic survey of temporal adverbials. We show that the hypotheses advanced by Nesset (2004) are confirmed by data from the ParaSol corpus. We propose that the accusative is the default case in the temporal adverbials under scrutiny and demonstrate that this lends support to the Constraint Hypothesis in (3).

Nesset (2004) suggests that the case distribution in temporal adverbials with 8 'in' depends on two factors, namely whether the governed noun denotes a bounded time span, and whether the time span in question is extended: ${ }^{3}$

(4) Boundedness and extendedness (length):

a. Bounded and shorter than a week $\rightarrow$ $\rightarrow$ accusative (в этусекунду in this second')

b. Bounded and longer than a week $\rightarrow$ в + locative (в этом годy in this year')

c. Unbounded $\rightarrow$ в + accusative (в наше время 'in our time')

Bounded time spans have boundaries as part of their meaning. These first and foremost include calendric notions with a clearly defined length such as месяц 'month' and год 'year', but also concepts like прошлое 'past' and будущее 'future', for which the present represents a boundary. Nesset (2004, 301-302) furthermore includes детство 'childhood', молодость 'youth' and старость 'old age' among the bounded time spans; although we do not know exactly when our childhood, youth and old age end, we all know that these periods will come to an end, so these are time spans with boundaries. Among the bounded time spans, Nesset $(2004,295$ and 315) argues that неделя 'week' forms a pivot, insofar as accusative is used for bounded time spans shorter than a week, while

\footnotetext{
${ }^{3}$ The constructions in (4) derive their meaning in part from the meaning of the preposition, and in part from the meaning of the case endings. Detailed discussion of how the semantic contributions of the preposition and case endings are integrated in the meaning of the constructions is beyond the scope of the present study. For an overview of the meanings of the Russian cases, see Janda and Clancy (2002).
} 
longer time spans combine with the locative, as illustrated in (4a-b). (Неделя itself normally combines with на 'on' + locative, cf. на прошлой неделе 'last week'.) Unbounded time spans are those that lack clearly defined boundaries, such as the generic term время 'time', as well as период 'period' and эпоха 'epoch'.4

Our database from the ParaSol corpus enabled us to test Nesset's (2004) hypotheses, as shown in Table 1, where the dashed lines single out the three groups of nouns in question, viz. short bounded (upper portion of the table), long bounded (middle portion), and unbounded (lower portion). In general, the data in Table 1 provides confirming evidence to the hypotheses, insofar as the accusative dominates for the short bounded and the unbounded spans, while the locative is the preferred option for long bounded time spans. (Notice that in Table 1 we distinguish between the singular and the plural, since this distinction will be important in the following.)

\begin{tabular}{lrrrrr} 
& $\mathrm{V}+\mathrm{Acc} \mathrm{Sg}$ & $\mathrm{V}+\mathrm{Acc} \mathrm{Pl}$ & $\mathrm{V}+\mathrm{Loc} \mathrm{Sg}$ & $\mathrm{V}+\mathrm{Loc} \mathrm{Pl}$ & Total \\
\hline миг 'instant' & 6 & 0 & 0 & 0 & 6 \\
мгновение 'instant' & 1 & 0 & 0 & 0 & 1 \\
момент 'moment' & 24 & 4 & 0 & 0 & 28 \\
секунда 'second' & 2 & 0 & 0 & 0 & 2 \\
минута 'minute' & 6 & 1 & 0 & 0 & 7 \\
час 'hour' & 17 & 6 & 2 & 0 & 25 \\
утро 'morning' & 1 & 0 & 0 & 0 & 1 \\
день 'day' & 22 & 11 & 0 & 0 & 33 \\
вечер 'evening' & 7 & 1 & 0 & 0 & 8 \\
ночь 'night' & 14 & 1 & 0 & 0 & 15 \\
полдень 'noon' & 4 & 0 & 0 & 0 & 4 \\
полночь 'midnight' & 1 & 0 & 0 & 0 & 1 \\
будни 'workdays' & 0 & 1 & 0 & 0 & 1 \\
суббота 'Saturday' & 1 & 0 & 0 & 0 & 1 \\
полнолуние 'full moon' & 1 & 0 & 0 & 0 & 1 \\
\hline неделя 'week' & 0 & 2 & 0 & 0 & 2 \\
месяч 'month' & 2 & 0 & 10 & 0 & 12 \\
год 'уеаr' & 4 & 6 & 8 & 0 & 18 \\
десятилетие 'decade' & 0 & 0 & 1 & 0 & 1 \\
детство 'childhood' & 0 & 0 & 4 & 0 & 4 \\
молодость 'youth' & 0 & 0 & 1 & 0 & 1 \\
старость 'old age' & 0 & 0 & 1 & 0 & 1
\end{tabular}

\footnotetext{
${ }^{4}$ Notice that our sample contains constructions with во время followed by a noun phrase in the genitive. Although such constructions may be analyzed as a complex preposition во время that governs the genitive case, we have included these constructions in our study, since they correspond to a variety of constructions in the other Slavic languages, and thus provide us with an opportunity to give a broader picture of the case variation in the North Slavic languages under scrutiny in the present study.
} 


\begin{tabular}{lrrrrr} 
век 'century' & 0 & 0 & 1 & 0 & 1 \\
столетие 'century' & 0 & 0 & 3 & 0 & 3 \\
будущеe 'future' & 0 & 0 & 8 & 0 & 8 \\
\hline время 'time' & 74 & 5 & 0 & 0 & 79 \\
период 'period' & 5 & 0 & 0 & 0 & 5 \\
эпоха 'еросh' & 2 & 0 & 0 & 0 & 2 \\
\hline Total & 194 & 38 & 39 & 0 & 271
\end{tabular}

Table 1: The distribution of $v+$ accusative vs. $v+$ locative in Russian

However, some examples call for comment. First of all, there are two examples where yac 'hour' combines with the locative rather than the expected accusative:

(5) $\mathrm{Ru}: \mathrm{B}$ первом часу дня немецкие солдаты подсчитывали свои трофеи. (Ostrovskij)

'Between twelve and one o'clock the German soldiers were counting up their booty.'

(6) Ru: Оставшаяся одна Анфиса, наплакавшись вволю, легла спать во втором часу ночи. (Bulgakov)

'Left alone, Anfisa, having wept her fill, went to sleep past one o' clock in the morning.'

Both sentences involve the same construction, where an event is located within a sixty minute time span (e.g. 'in the first hour', i.e. between 12 o'clock and 1 o'clock). Although this construction involves time spans shorter than a week, it has a strong focus on boundedness, which arguably motivates the use of the locative case (cf. Nesset 2004, 296 for discussion).

Among the long bounded time spans, we have two attestations of месяц 'month' and four with 200 'year' that display the accusative singular instead of the expected locative. Three of these examples involve what we may call the "modifier effect"; Nesset $(2004,308-312)$ observes that modifiers under certain circumstances favor the accusative case. If the modifier is a postposed NP in the genitive, the accusative is an absolute rule. The following example is illustrative:

(7) $\mathrm{Ru}:$ B тот апрель мятежного девятнадцатого года обалделый обыватель спрашивал ранее проснувшегося соседа: - Автоном Петрович, какая власть в городе? (Ostrovskij)

'That April of the rebellious year 1919 the confused resident asked his neighbor who had woken up earlier: - Avtonom Petrovič, who is in power in town?'

Nesset (2004, 308-312) argues that modifiers such as мятежного девятнадцатого года 'of the rebellious year 1919' change the focus from quantitative to qualitative; rather than just locating the event in time, the elaborate description emphasizes what kind of time we are dealing with. When the focus is qualitative instead of quantitative, the accusative is the rule.

Preposed adjectival modifiers favor the accusative case less consistently than postposed NPs in the genitive. However, we find the accusative in examples 
such as (8), where the emphasis is not quantitative, i.e. not on the temporal boundaries within which the events took place, but rather qualitative, insofar as the sentence describes the circumstances (rain) which accompanied the events in question:

(8) $\mathrm{Ru}$ Только в дождливый ноябрь стало твориться что-то неладное. (Ostrovskij)

'Only during the rainy month of November something strange started happening.'

In Contemporary Standard Russian, the preposed modifier mom 'that' combines with both the accusative and the locative, but the accusative appears to dominate in anaphoric uses. This is not unexpected. When a month or year has been mentioned previously, it has already been located in time. When it is mentioned again, it is associated with a property, namely that of being known to both speaker and addressee. Arguably, therefore, the focus is more qualitative than quantitative. Example (9) is of this anaphoric type:

(9) $\mathrm{Ru}$ День становился жарким, такой жары в тот год еще не было. (Süskind)

'It turned out to be a hot day, the hottest of the year thus far.'

Our final three attestations where zod 'year' is not in the locative involve what we may call the "age construction", which specifies at what age someone did something. Notice that in this construction zod 'year' does not specify a long bounded time span, but rather a point in time (notice that the corresponding English construction uses the preposition at, which is used for points):

(10) $\mathrm{Ru}$ Этот маркиз уже в сорок лет потерял интерес к придворной жизни, покинул Версаль, удалился в свои владения и посвятил себя наукам. (Süskind)

'At the age of forty, the marquis had turned his back on life at the court of Versailles and retired to his estates, where he lived for science alone.'

(11) $\mathrm{Ru}$ : Он встал на обе ноги только в три года, первое слово произнес - в четыре. (Süskind)

'Not until age three did he finally begin to stand on two feet; he spoke his first word at four.'

Since we are dealing with a point on the timeline instead of a long bounded time span, the use of the accusative is expected. Notice that $8+$ accusative is used in constructions such as в тот момент 'at that point', which refer to a point in time.

Another factor discussed by Nesset $(2004,302-308)$ is what we may refer to as the "plural effect". Whereas a singular phrase like эmom год 'this year' has an exact length (365 days) and hence clearly defined boundaries, the plural phrase эти годы 'these years' does not denote a bounded time span with clearly defined boundaries. Since pluralization, as it were, removes temporal boundaries and creates unbounded time spans, we expect temporal nouns in the plural to occur in the accusative after 8 'in'. As can be seen from Table 1, this prediction is 
borne out by the facts; regardless of their lexical meanings, all temporal nouns in the plural are in the accusative. ${ }^{5}$

A final factor explored by Nesset $(2004,298-302)$ may be dubbed the "cyclicity effect". In Russian nouns that describe parts of the daylight cycle (ympo 'morning', день 'day', вечер 'evening', and ночь 'night') or the cycle of seasons combine with the bare instrumental case as in (12) or (less frequently) $8+$ the accusative as in (13): ${ }^{6}$

(12) $\mathrm{Ru}:$ Этим летом я жил с пастухами на альпийских лугах Башкапсара. [Искандер 1969]

'That summer I lived with the herdsmen in the alpine meadows of Bashkapsar.'

(13) Ru: В это лето они действительно были счастливы. [Беляков 1998] 'That summer they really were happy.'

Notice that the cyclicity effect overrides the extendedness (length) factor; even though the seasons are longer than a week, they combine with 8 and the accusative, as shown in (13). There are no examples of this type in our data from the ParaSol corpus, however, so examples (12) and (13) are from the Russian National Corpus.

We are now in a position to summarize our discussion as a set of precise generalizations:

(14) Generalizations for Russian:

a. Long bounded non-cyclic time spans in the singular without qualityfocusing modifiers $\rightarrow$ b + locative

b. Cyclic time spans $\rightarrow$ bare instrumental or $8+$ accusative

c. Elsewhere $\rightarrow$ $8+$ accusative

In addition to the epithets "long" and "bounded" which refer to the extendedness (length) and boundedness factors, "non-cyclic" is included in (14a) to rule out "cyclic" time spans such as the seasons. The conditions "in the singular" and "without quality-focusing modifiers" in (14a) capture the pluralization and modifier effects discussed above.

The generalizations in (14) facilitate two observations. First, they demonstrate that in Russian the accusative is the default in the relevant kind of temporal adverbials; while the locative is used under a limited set of clearly defined conditions, the accusative is used in all other contexts. Second, the

\footnotetext{
5 The fact that pluralization removes temporal boundaries and therefore provides motivation for the accusative case can be overridden in certain constructions. An example is the "decade construction", where we observe vacillation between accusative and locative as shown by examples like в сороковые годы vs. в сороковых годах. For a discussion of this construction the reader is referred to Nesset 2004, 303-308.

${ }^{6}$ We follow traditional practice and use the term "cyclic" about 'day', 'night', 'morning', 'evening' and the seasons as opposed to "calendric" notions such as the months. Notice in passing, however, that this is not quite precise, since calendric notions are also organized in cycles (cf. Fauconnier and Turner 2008). When December is over, we go back to the beginning of the cycle, namely January.
} 
generalizations in (14) show that in temporal adverbials, the two cases are in complementary distribution after $в$ 'in', since the two cases are used in nonoverlapping environments (i.e. for different classes of temporal nouns). We use "complementary distribution" in the same way as the term is traditionally used about allophones and allomorphs. Simplifying somewhat, Russian has a fronted a-sound when it is flanked by soft consonants (e.g. мять 'crumple'), while a more back vowel is pronounced between hard consonants (e.g. Mam 'mate') (see Nesset 2008, 32 for a more detailed discussion). Since these two vowels occur in non-overlapping environments, they are considered allophones in complementary distribution. In the verbs войти 'walk in' and вбежать 'run in' the prefix has different shapes; 8 - and 80 - are regarded as allomorphs in complementary distribution because they occur in non-overlapping environments (cf. Baayen et al. this volume). Characteristic of elements in complementary distribution is the fact that we can predict which element is used from the environment. This holds for the accusative vs. locative cases in temporal adverbials too. On the basis of the lexical meaning of the governed noun (in addition to its number and the modifiers with which it combines) it is possible to predict the choice between the two cases.

The second observation enables us to address the question raised in the beginning of the article about space-time asymmetries: is there a parallel complementary distribution in the domain of space? The answer to this question is clearly in the negative. The choice between the accusative and the locative after 8 'in' in spatial expressions does not depend on the meaning of the governed noun, and boundedness and extendedness are certainly irrelevant. As shown in (15) and (16), unbounded nouns such as космос 'cosmos' combine with both cases:

(15) Ru: А когда мне было 11 лет, Гагарин полетел в космос. [«Дело» 2002] 'When I was 11 years old, Gagarin flew into outer space.'

(16) Ru: Как долго сможет он находиться в космосе? [«Юность» 1971] 'How long will he be able to stay in outer space?'

Sentence (17) indicates that the locative is compatible with spatial nouns such as точка 'point' that are conceptualized as having no spatial extension, while (18) shows that accusative combines with vast bounded spaces such as Россия 'Russia':

(17) $\mathrm{Ru}:$ Нажал человек кнопку - и органы уже оповещены, что гражданин с такими-то именем и фамилией, находящийся в точке с такими-то координатами, в опасности. [«Известия» 2002]

'One could press a button, and the organs would already know that a citizen with a certain name located in a spot with certain coordinates, would be in danger.'

(18) Ru: В следующем, 1931-м году Горький снова поехал в Россию. [Берберова 1978-1980]

'In the following year, 1931, Gorky went to Russia again.'

In the domain of space, the distribution of the two cases is not complementary, but rather contrastive; as any grammar will tell you, the accusative is used to 
indicate movement or direction into a three-dimensional space, while the locative signals location within such a space (cf. e.g. Isačenko 1984, 567; Švedova (Ed.) 1980, 445-446 and 452). ${ }^{7}$ The upshot of this is that we are dealing with a space-time asymmetry: in time, the two cases are in complementary distribution, whereas in space the distribution of the cases is contrastive. With this in mind, we turn to the analysis of other Slavic languages.

\section{Belarusian}

Given the close genetic relationship and geographical proximity, it is not surprising that the Belarusian system of temporal adverbials is very similar to the Russian system. However, our material brings out some differences regarding the use of the bare genitive, bare instrumental and the preposition $a$ (the cognate of the Russian preposition $o$ ) + locative.

\begin{tabular}{|c|c|c|c|c|c|c|c|c|c|}
\hline & $\begin{array}{r}\mathrm{V}+\mathrm{A} \\
\mathrm{Sg}\end{array}$ & $\begin{array}{r}\mathrm{V}+\mathrm{A} \\
\mathrm{Pl}\end{array}$ & $\begin{array}{r}\mathrm{V}+\mathrm{L} \\
\mathrm{Sg}\end{array}$ & $\begin{array}{r}\mathrm{V}+\mathrm{L} \\
\mathrm{Pl}\end{array}$ & $\begin{array}{r}\text { Bare } \\
\text { G }\end{array}$ & $\begin{array}{r}\text { Bare } \\
\mathrm{A}\end{array}$ & $\begin{array}{r}\text { Bare } \\
\text { I }\end{array}$ & other & Total \\
\hline імгненне 'instant' & 3 & & & & & & & & 3 \\
\hline момант 'moтепt' & 23 & 2 & & & & & & 1 & 26 \\
\hline мінута 'minute' & 2 & & & & & & & & 2 \\
\hline секунда 'second' & 2 & & & & & & & & 2 \\
\hline хвіліна 'minute' & 3 & 3 & & & & & & & 6 \\
\hline хвіля 'minute' & 1 & & & & & & & & 1 \\
\hline гадзіна'hour' & 13 & 5 & & & & & & 5 & 23 \\
\hline полудзень 'пооп' & 1 & & & & & & & & 1 \\
\hline поўдень 'пооп' & & & & & & & & 3 & 3 \\
\hline поўнач 'midnight' & & & & & & & & 1 & 1 \\
\hline раніца 'morning' & & & & & & & 1 & & 1 \\
\hline дзень 'dау' & 18 & 6 & & & 3 & & 2 & 3 & 32 \\
\hline вечар 'evening' & 4 & 1 & & & 2 & & 1 & & 8 \\
\hline ноч 'night' & 10 & 1 & 1 & & 3 & & & 1 & 16 \\
\hline субота 'Saturday' & 1 & & & & & & & & 1 \\
\hline нядзеля 'Sunday' & 1 & & & & & & & & 1 \\
\hline тыдзень 'week' & & & & & & 2 & & & 2 \\
\hline місяць 'month' & 2 & & 10 & & & & & & 12 \\
\hline лето 'Summer' & & & & & 1 & & & & 1 \\
\hline
\end{tabular}

\footnotetext{
${ }^{7}$ At this point the question arises as to why long and bounded time spans behave like locations in space, since both constructions have $8+$ the locative. In the same way, one may wonder why goals in space and short/unbounded time space combine with $8+$ the accusative. Although these questions are tangential to the present study, we note that Nesset (2004) provides a partial explanation in terms of the container image schema. Containers are suitable for location, and the time spans that are most easily seen as metaphorical containers are arguably the bounded and long ones. Clearly, in order for something to be conceptualized as a container, it needs to have boundaries, since all containers have clear boundaries (edges). Furthermore, longer time spans are more naturally conceptualized as containers, while shorter time spans tend to be conceptualized as points.
} 


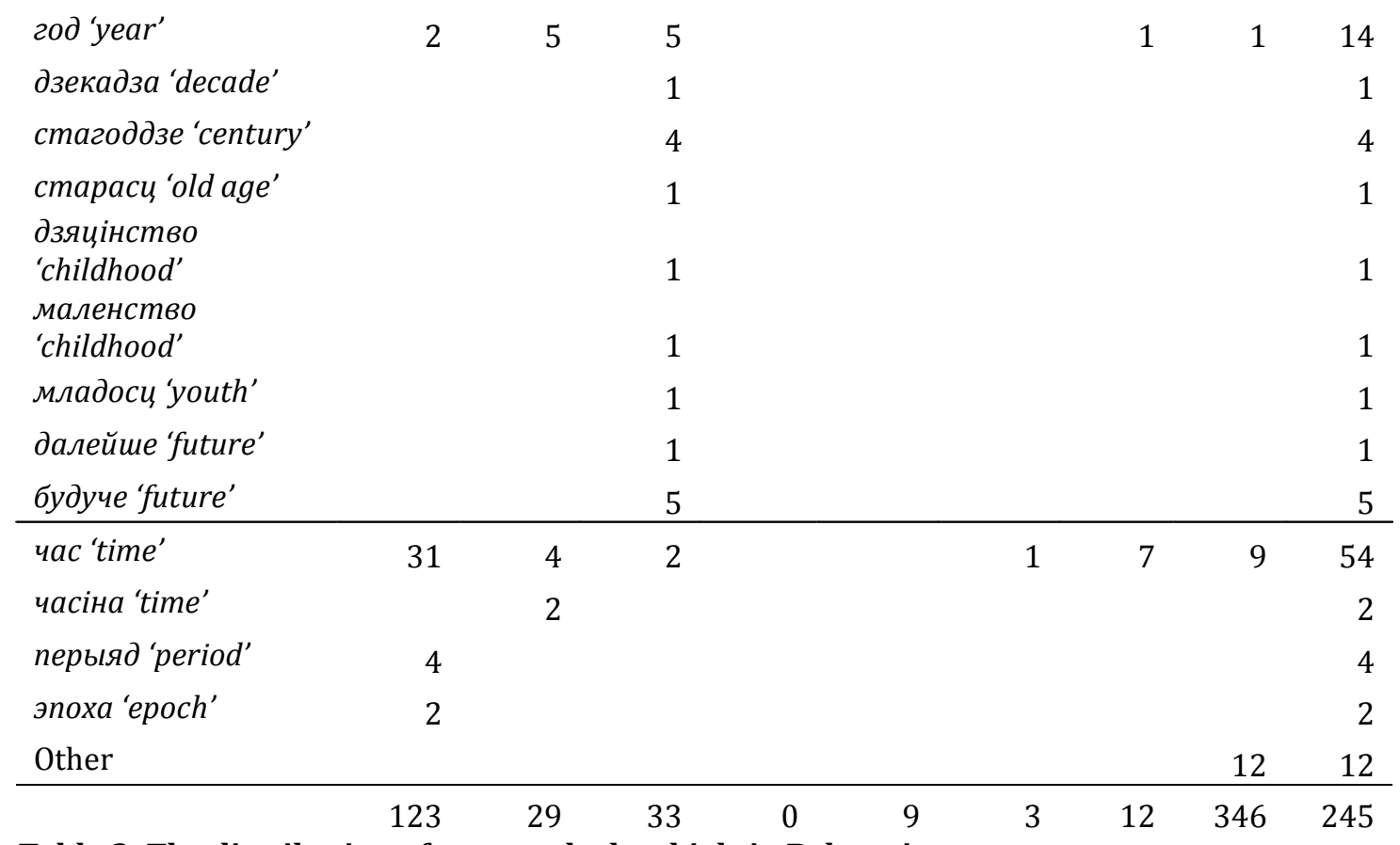

Table 2: The distribution of temporal adverbials in Belarusian

The first question we must ask is whether the distribution of the accusative and the locative cases after 8 is different from Russian. The data in Table 2 indicate that the two languages have very similar systems. ${ }^{8}$ For short bounded time spans, the accusative is the rule; there is only example with a short bounded time span in the locative:

(19) Bl: Заўтра ўночы ў горадзе, як і ў іншых гарадах Украіны, павінна ўспыхнуць контррэволюцыйнае паўстанне. (Ostrovskij)

'The next night in the town, like in other towns in the Ukraine, a counterrevolutionary rebellion was supposed to break out.'

While the parallel example in Russian has $8+$ the accusative, it should be noted that в ночи in the locative is attested in Russian. As pointed out by Nesset (2004, 316, see also Rubinstein 2001, 4-5), the emphasis in Russian examples with the locative is on the "darkness of the night rather than on time as such". In other words, this construction is more spatial than temporal, and thus locative is the preferred option. Data from the Russian National Corpus lend support to this analysis. The following sentence, where огонёк 'spark, small light' implies focus on light vs. darkness, is typical:

(20) $\mathrm{Ru}$ В жизни Кямала обозначилась надежда, как огонёк в ночи. [Токарева 2002]

'In Kemal's life, hope took shape like a spark in the night.'

\footnotetext{
${ }^{8}$ Notice that the total number of Belarusian examples in Table 2 is only 245, although there are 271 Russian examples in Table 1. This is because some Russian temporal adverbials were not translated, or the Belarusian translations have chosen other means of expressing the temporal relations in question. The same holds for Ukrainian, Polish and Czech.
} 
It is interesting that (19) contains the verb ууспыхнуць 'flare up', which implies metaphorical light. We speculate that in Belarusian, the use of the locative with ноч 'night' extends to metaphorical light, whereas in Russian this construction is restricted to literal light. However, our data material is too limited to facilitate strong claims to this effect.

For long bounded time spans, Table 2 shows that the locative is the rule. With nouns in the singular, there are only two examples with months and two with year that involve $\breve{y} / y$ followed by the accusative case. However, these examples do not represent differences between Russian and Belarusian, but rather show that Belarusian shares the "modifier effect" with Russian. In one of the examples with month, which parallels (8) in Russian, we are dealing with an adjectival modifier implying focus on quality rather than quantity:

(21) Bl: Толькі $\breve{\mathbf{y}}$ дажджлівы лістапад пачало тварыцца нешта незразумєпае. (Ostrovskij)

'Only during the rainy month of November something strange started happening.'

The same holds for sentences with postposed genitive modifiers, as shown by example (22), which parallels (7) in Russian:

(22) Bl: У той красавік мяцежнага дзевятнаццатага года адурнелы абываталь трывожна пытаў у суседа, што прачнуўся раней: - Аўтаном Пятровіч, якая ўлада ў горадзе? (Ostrovskij)

'That April of the rebellious year 1919 the confused resident asked his neighbor who had woken up earlier: - Avtonom Petrovič, who is in power in town?'

The two examples with rod 'year' in the accusative specify a point on the age scale when something happened. As mentioned in section 2, Russian has $8+$ accusative in this construction, since $20 \partial$ here represents a point rather than a long bounded time span. Belarusian parallels Russian, as illustrated by the following sentence:

(23) Bl: Ён устаў на абедзве ножкі толькі ў тры гады, першае слова вымавіў -- у чатыры. (Süskind)

'Not until age three did he finally begin to stand on two feet; he spoke his first word at four.'

What about unbounded time spans in Belarusian? Again our data indicate how similar Belarusian is to Russian. Of the 45 examples involving yac 'time', часіна 'time', перыяд 'period' and эпоха 'epoch' preceded by $y / y, 43$ display the accusative case in Belarusian, indicating that the accusative is the rule for unbounded time spans in Belarusian.

In addition to the constructions with $\breve{y} / y$, which parallel the use of $\theta+$ the accusative or locative in Russian, our data material illustrates the use of the bare accusative, genitive and instrumental in Belarusian temporal adverbials. In Russian, the bare accusative is used to signal the duration or repetition of an event, while location in time is marked by prepositional phrases with 8 and other 
prepositions. Simply put, in Russian the questions как долго? 'for how long?' (duration) and как часто? 'how often?' (repetition) are answered by means of bare NPs in the accusative, such as весь вечер 'the whole evening' and каждый день 'every day', whereas the question когда? 'when' indicating location in time is answered by prepositional phrases (e.g. в понедельник 'on Monday'). Even though our database testifies to the close similarity of Russian and Belarusian, it is interesting to note that Belarusian displays the bare accusative in three cases where Russian has prepositional phrases:

(24) Bl: Апошнія тыдні і месяцы ён ужо больш не карміўся гатаванай чалавекам ежай. (Süskind)

'In the past weeks and months he had no longer fed himself with food processed by human hands.'

(25) Bl: Першыя тыдні ён яшчэ некалькі разоў падымаўся на вяршыню, каб абнюхаць усё навокал. (Süskind)

'He climbed back up to the peak a few more times during the first weeks to sniff out the horizon.'

(26) Bl: Адное толькі тое што Грануй увесь час свайго затачэння харчаваўся аддаленымі ад зямлі раслінамі. (Süskind)

'All that had prevented his death was that during his imprisonment Grenouille had been given earth-removed plants.'

Examples of this kind suggest that the distinction between location in time and duration is less clear-cut in Belarusian than in Russian, but our limited data material prevents us from making any strong claims.

In Contemporary Standard Russian the bare genitive (genitivus temporis) is productive only with dates:

(27) $\mathrm{Ru}:$ Сказал, что я сам виноват в том, что случилось первого апреля. [Геласимов 2001]

'He said I was to blame for what happened on the first of April.'

However, a few set expressions such as третьего дня 'two days ago' and adverbializations like сегодня 'today' testify to the wider distribution of this construction in earlier times; as pointed out by Grannes (1986, 60; see also Bulaxovskij 1954, 333) the genitivus temporis was used widely in Old Russian, but had a "swift decline" in the 18th century and the beginning of the 19th century. Our data show that in Belarusian the bare genitive has a wider sphere of use than in Russian; we have nine Belarusian examples with the bare genitive where Russian has the preposition 6 . Consider the following representative examples:

(28) Bl: Гэта адбылося толькі таго дня ў сакавіку, калі ён сядзеў на кастры. (Süskind)

'It happened first on that March day as he sat on the cord of wood.'

(29) Bl: Першага ж вечара Граную давялося намяшаць вялікі балон "Неапалітанскай ночы". (Süskind)

'The very first evening, Grenouille had to prepare a large demijohn full of Nuit Napolitaine.' 
(30) Bl: Каля штольні ён апрануўся ў свае лахманы, накінуў на плечы гуньку і тае ж ночы пакінуў Плён-дзю-Канталь і пайшоў на поўдзень. (Süskind)

'Outside he pulled on his rags, threw the horse blanket over his shoulders, and that same night left the Plomb du Cantal, heading south.'

(31) Bl: Дзень уграваўся, такое гарачы, як таголета, яшчэ не было. (Süskind)

'It turned out to be a hot day, the hottest of the year thus far.'

The examples suggest that there are three conditions for the use of the bare genitive in Belarusian: (a) the time span in question normally belongs to the natural cycle of the day (morning, day, evening, night), (b) the temporal noun is preceded by a determiner or modifier, mostly moŭ 'that', and (c) the temporal noun is in the singular. An interesting question concerns the relationship between (b) and (c). Why do pronominal modifiers and the singular favor the bare genitive? We speculate that both pronominal modifiers and the singular narrow down the range of potential referents, and that this is in harmony with the use of the genitive as a "reference point construction" (Langacker 2009). For instance, in possessive constructions such as Peter's car, the possessor (Peter) is a reference point that facilitates the identification of the car in question. Likewise, a modifier and the singular help identify the time span in question as a reference point.

In our discussion of Russian in section 2, we mentioned the "cyclicity effect", whereby time spans belonging to the natural cycles of the day and the year occur in the bare instrumental. Example (32) shows that the bare instrumental is attested in such nouns in Belarusian, too:

(32) Bl: Доўга будзіў гэтай раніцай галубоўскага ад'ютанта Паляныцю начальнік галубоўскага канвою Саламыга. (Ostrovskij)

'This morning it took the commander of the Golubov convoy, Salomyga, a long time to wake up aide-de-camp Paljanyca.'

The corresponding sentence in Russian has в это утро. According to Lomtev (1956, 246), in Belarusian the bare instrumental is furthermore used for calendric time spans in the plural and unbounded time spans. Examples (33) and (34) show that Lomtev's observations are correct:

(33) Bl: У яго пачалася моцная гарачка, першымі днямі з вялікім паценнем, а потым, калі перасталі функцыянаваць поры ў скуры, усё цела пайшло нарывамі. (Süskind)

'He came down with a high fever, which for the first few days was accompanied by heavy sweats, but which later, as if the pores of his skin were no longer enough, produced countless pustules.'

(34) Bl: Дзіўная стрыманасць, з якой ён звяртаўся да мяне апошнім часам, знікла. (Lem)

'The strange restraint, with which he had spoken to me lately, had disappeared.' 
In the column labeled "other" in Table 2 , we find a number of constructions with prepositions, one of which we will comment on, since it illustrates an important difference between Russian and Belarusian. We have nine Belarusian examples with $a+$ locative involving the words for 'hour', 'midday' and 'midnight' (which are also hours). The $a+$ locative construction is compatible with exact and approximate timing (examples (35)-(36)), and also corresponds to the Russian construction 8 ... часу 'during the ... hour', as shown in (37):

(35) Bl: А дзевятнаццатай гадзіне бартавога часу я прайшоў міма тых, хто сабраўся вакол шлюзавой камеры. (Lem)

'At seven sharp local time I passed those who gathered around the lock chamber.'

(36) Bl: Прыходзь заўтра раніцай а дзевятай да Сарторыуса. (Lem)

'Come tomorrow morning at around nine to Sartorius.'

(37) Bl: Анфіса, якая засталася адна, наплакаўшыся ўволю, легла спаць а другой гадзіне ночы. (Bulgakov)

'Left alone, Anfisa, having wept her fill, went to sleep past one o' clock in the morning.'

Notice that in (36) approximate timing is marked by inverted word order in the same way as in Russian часов в девять means 'approximately at nine o'clock'. It appears that the prepositional construction with $a+$ locative is a marker of exact timing in Belarusian, but that inverted word order trumps this and yields approximate time, just like Russian $\theta$ indicates exact timing in Russian unless the word order is inverted. It is worth mentioning that the Russian preposition $o$, the cognate of Belarusian $a$, is attested in temporal adverbials, albeit not in our database. As demonstrated by Endresen (this volume), the temporal $o+$ locative construction has become fairly marginal in Contemporary Standard Russian.

The following generalizations summarize our discussion of temporal adverbials in Belarusian: ${ }^{9}$

(38) Generalizations for Belarusian:

a. Long bounded non-cyclic time spans in the singular without qualityfocusing modifiers $\rightarrow \breve{y} / y+$ locative

b. Cyclic time spans (morning, day, evening, night) in the singular preceded by determiner/modifier (mostly moŭ) $\rightarrow \breve{y} / y+$ accusative or bare genitive

c. Cyclic/unbounded time spans $\rightarrow \breve{y} / y+$ accusative or bare instrumental

d. Hour, midday, midnight $\rightarrow \breve{y} / y+$ accusative or $o+$ locative

e. Elsewhere $\rightarrow \breve{y} / y+$ accusative

Although we have identified differences, in general the Belarusian system of temporal adverbials strongly resembles the Russian system. The generalizations in (38) show that in Belarusian like in Russian the accusative and locative cases are in complementary distribution in temporal adverbials; the choice of case is predictable from the meaning of the temporal noun and some additional

\footnotetext{
${ }^{9}$ We do not include the bare accusative in our set of generalizations, since for this construction our data material is too limited.
} 
information about its morphological properties and syntactic environment. In the domain of space on the other hand, the two cases are contrastive, insofar as the locative signifies location within a three-dimensional space, while the accusative marks direction/movement into such a space (cf. Lomtev 1956, 234241). In other words, while the Belarusian and Russian systems are not identical, both languages display the same kind of space-time asymmetry, thus lending support to the Constraint Hypothesis advanced in section 2.

\section{Ukrainian}

We now turn to Ukrainian, which has a system of temporal adverbials that is close to the Belarusian system we have just discussed. However, we will show that compared to Belarusian, Ukrainian is somewhat further removed from Russian since Ukrainian displays a wider use of the bare genitive and the $o+$ locative constructions than Belarusian.

The data summarized in Table 3 testify to the similarities between Ukrainian and its East Slavic relatives, Russian and Belarusian. For long bounded time spans the locative dominates after the preposition $y / \beta$ (the cognate of Russian 8 ), while accusative is the rule for short bounded time spans as well as time spans that are unbounded. In the same way as in Russian and Belarusian, the table shows that there is a plural effect in Ukrainian, insofar as the accusative dominates for plural forms of nouns denoting long bounded time spans.

\begin{tabular}{|c|c|c|c|c|c|c|c|c|c|}
\hline & $\begin{array}{r}\mathrm{V}+\mathrm{A} \\
\mathrm{Sg}\end{array}$ & $\begin{array}{r}\mathrm{V}+\mathrm{A} \\
\mathrm{Pl}\end{array}$ & $\begin{array}{r}\mathrm{V}+\mathrm{L} \\
\mathrm{Sg}\end{array}$ & $\begin{array}{r}\mathrm{V}+\mathrm{L} \\
\mathrm{Pl}\end{array}$ & $\begin{array}{r}\text { Bare } \\
\text { G }\end{array}$ & $\begin{array}{r}\text { Bare } \\
\mathrm{A}\end{array}$ & $\begin{array}{r}\text { Bare } \\
\text { I }\end{array}$ & Other & Total \\
\hline мить 'instant' & 15 & & & & 2 & & & & 18 \\
\hline момент 'moтепt' & 6 & 1 & & & & & & & 7 \\
\hline південь 'пооп' & & & & & & & & 4 & 4 \\
\hline північ 'midnight' & & & & & & & & 1 & 1 \\
\hline хвилина 'minute' & 4 & 2 & & & & & & & 6 \\
\hline ранок 'тоrning' & & & & & 1 & & & & 1 \\
\hline день 'day' & 7 & 10 & & & 16 & & 1 & 1 & 35 \\
\hline вечір 'evening' & 2 & 1 & & & 4 & & 1 & & 8 \\
\hline ніч 'night' & 2 & 1 & 1 & & 11 & & & 1 & 16 \\
\hline година 'hour' & 2 & 3 & & & & & & 19 & 24 \\
\hline тиждень 'week' & & 1 & & & & 1 & & 1 & 3 \\
\hline місяи 'month' & & & 8 & & 1 & & & 1 & 10 \\
\hline piк 'year' & 3 & 6 & 5 & & 5 & & & & 19 \\
\hline століття 'century' & & & 4 & & & & & & 4 \\
\hline дитинство 'childhood' & & & 1 & & & & & & 1 \\
\hline cmapicmь 'old age' & & & & & & & & 1 & 1 \\
\hline pas 'bout' & 1 & & & & & & & & 1 \\
\hline майбутнє 'future' & & & 3 & & & & & & 3 \\
\hline nepiod 'period' & 4 & & & & & & & & 4 \\
\hline час 'time' & 16 & 9 & & & & & 5 & 2 & 32 \\
\hline Other & & & & & & & & 33 & 33 \\
\hline Total & 62 & 34 & 22 & 0 & 40 & 1 & 7 & 64 & 231 \\
\hline
\end{tabular}


Table 3: The distribution of temporal adverbials in Ukrainian

Only a few examples with $y / в$ require comment. Like in Belarusian (but unlike Russian) there is one example where ніч 'night' combines with the locative. Sentence (39) is the same sentence as (19) in Belarusian:

(39) Uk: Завтра вночі в місті, як і по всій Україні, повинно спалахнути контрреволюційне повстання. (Ostrovskij)

'The next night in the town, like in other towns in the Ukraine, a counterrevolutionary rebellion was supposed to break out.'

While for long bounded time spans $y / 6$ is normally followed by the locative case, there are three attestations of the accusative. However, these examples involve the "age construction", where the accusative is used in Russian and Belarusian, too. The following example, which parallels (11) and (23), illustrates this:

(40) Uk: Аж у три роки він став на обидві ноги, перше слово промовив у чотири. (Süskind)

'Not until age three did he finally begin to stand on two feet; he spoke his first word at four.'

It is interesting to note that there is no trace of a modifier effect in our Ukrainian data. Recall from section 2 that in Russian 8 governs the accusative if a long bounded time span is accompanied by modifiers involving a qualitative focus, as illustrated in examples (7)-(9). In the example corresponding to (7), where Russian has a postposed modifier, Ukrainian has the bare genitive construction, which we will return to below:

(41) Uk: Того квітня буремного дев'ятнадцятого року очманілий обиватель тривожно питав сусіда, що прокинувся раніше: - Автономе Петровичу, яка влада в місті? (Ostrovskij)

'That April of the rebellious year 1919 the confused resident asked his neighbor who had woken up earlier: - Avtonom Petrovič, who is in power in town?'

In the examples corresponding to (8) and (9), where Russian has preposed modifiers, Ukrainian displays $y / 8$ followed by the locative:

(42) Uk: Тільки в дощовому листопаді почало коїтися щось непевне. (Ostrovskij)

'Only during the rainy month of November something strange started happening.'

(43) Uk: День був спекотний, найспекотніший у цьому році. (Süskind)

'It turned out to be a hot day, the hottest of the year thus far.'

In order to investigate the modifier effect further, we excerpted all examples with Russian $8+20 \partial$ in the accusative singular from the parallel corpus in the 
Russian National Corpus. ${ }^{10}$ Of the twelve attestations of temporal adverbials of the relevant type in Russian, five had the bare genitive, while in five Ukrainian examples there were no corresponding temporal adverbials. The remaining two examples displayed $y / 6$ + the accusative:

(44) Uk: Можливо, раніше я занадто остуджував Едикові пориви, а в останній рік просто висів над його головою. [Мушкетик 1985]

'Earlier I strongly restrained Edik's attempts, but last year I followed him even more closely.'

(45) Uk: Всі епіграфи Пікассо на титулах-3 його п'єси "Пожадання, впіймане за хвіст", написаної у перший рік окупації Парижа гітлерівцями. [Загребельний 1962-1968]

'All the epigraphs by Picasso are from the play "Desire caught by the tail", which was written during the first year of the Fascist occupation of Paris.'

While the material from the ParaSol corpus and the Russian National Corpus is too limited to allow for strong claims, examples like (44) and (45) indicate that the accusative is possible in combination with modifiers in Ukrainian. However, at the same time examples (42) and (43) suggest that the modifier effect is weaker in Ukrainian than in Russian and Belarusian, and that the locative has a somewhat wider distribution in Ukrainian.

We now turn to the use of the bare cases. The bare accusative occurs in one example - the example that corresponds to (24) in Belarusian - so our material does not afford any conclusions about the use of the bare accusative in Ukrainian. As for the bare genitive, this construction seems to have a stronger position in Ukrainian than in Belarusian; we have 42 attestations in Ukrainian, but only nine in Belarusian. The Ukrainian examples with the bare genitive cover a wider sets of nouns. Like in Belarusian the center of gravity in Ukrainian is the day cycle (morning, day, evening, night), which accounts for 33 of the 42 examples. However, in Ukrainian we also have attestations with мuть 'moment', місяць 'month' and рік 'уеar'. The examples with місяць and рік show that the bare genitive is compatible with both cyclic and calendric time spans. As in Belarusian the bare genitive combines with modifiers; all the Ukrainian examples with the bare genitive involve modifiers, most commonly pronouns such as moŭ 'that'.

While the bare genitive is stronger in Ukrainian than in Belarusian, the opposite holds for the bare instrumental; we have only six attestations in Ukrainian, while Belarusian has twelve. Of the six attestations in Ukrainian, one has день 'day', while the remaining five involve час 'time'. The following example with yac illustrates the use of the bare instrumental with unbounded time spans, which is attested in both Belarusian and Ukrainian:

\footnotetext{
10 The parallel subcorpus of the Russian National Corpus (www.ruscorpora.ru) contains 370 documents (approximately 24022437 words). Corpus searches were performed in May 2012. We allowed for a maximum of three words between the preposition and the temporal noun.
} 
(46) Uk: Підозріла стриманість, з якою він звертався до мене останнім часом зникла. (Lem)

'The strange restraint, with which he had spoken to me lately, had disappeared.'

In the same way as in Belarusian, the construction with the preposition $o+$ locative is attested in Ukrainian. However, we have more than twice as many attestations in Ukrainian (23 vs. 9 in Belarusian), so it seems safe to conclude that the construction has a stronger position in Ukrainian. The construction covers the same time spans in the two languages, but in Ukrainian the vast majority of the examples (eighteen) involve година 'hour':

(47) Uk: О сьомій годині ранку Павка передав киплячі самовари своїй зміні. (Ostrovskij)

'At seven o'clock in the morning Pavka handed over the boiling samovars to his shift.'

The following generalizations summarize our discussion of temporal adverbials in Ukrainian, and show that the Ukrainian system is very close to its Belarusian sister.

(48) Generalizations for Ukrainian:

a. Long bounded non-cyclic time spans in the singular (without qualityfocusing modifiers) $\rightarrow y / \beta+$ locative

b. Cyclic/unbounded time spans $\rightarrow y / \beta+$ accusative or (bare instrumental)

c. (Cyclic) time spans (morning, day, evening, night) preceded by determiner/modifier (mostly moŭ) $\rightarrow y+$ accusative or bare genitive

d. Hour, midday, midnight $\rightarrow(y / \beta+$ accusative or $) o+$ locative

e. Elsewhere $\rightarrow y / b+$ accusative

However, there are four subtle differences between the generalizations for Ukrainian in (48) and Belarusian in (38). First, in (48a) we have included the phrase "without quality-focusing modifiers" in parentheses since the modifier effect seems less pronounced in Ukrainian. Second, "bare instrumental" is included in parentheses in (48b), because we have indications that this construction has a weaker position in Ukrainian compared to Belarusian. Third, "cyclic" is parenthesized in (48c), since the bare genitive to a lesser degree is restricted to cyclic time spans in Ukrainian than in Belarusian. Last but not least, we have observed that the $o$ + locative is stronger in Ukrainian, and in order to capture this " $y / 6+$ accusative" is included in parentheses in (48d).

While the use of parentheses only provides an informal and impressionistic account of the differences between Belarusian and Ukrainian, it is sufficiently precise to show that Ukrainian is further removed from Russian compared to Belarusian. However, the differences are small, and Ukrainian shares with its East Slavic relatives the fact that the accusative and locative are in complementary distribution. Since all the East Slavic languages have contrastive distribution of the accusative and locative cases in spatial constructions (motion/direction vs. location, Vyxovanec' and Gorodens'ka 2004, 333-338), Ukrainian is like Russian and Belarusian in that it displays a space-time 
asymmetry. In other words, all the East Slavic languages lend support to the Constraint Hypothesis discussed in section 2.

\section{Polish}

As we turn to the western branch of the Slavic languages, we see that the accusative becomes less important, while the locative serves as the default case in temporal adverbials. However, we will also show that Polish resembles Ukrainian and Belarusian in the use of the bare genitive and the construction with $o$ followed by the locative case.

Table 4 provides an overview of the situation in Polish. Compared to the East Slavic languages, Polish displays a stronger preference for the locative case after the preposition $w$ (which is the cognate of Russian $v$ ). The locative is the preferred option for short bounded, long bounded as well as for unbounded time spans; in other words, Polish reveals no sensitivity to boundedness or extendedness. Moreover, there is no plural effect; while in East Slavic the plural has an affinity for the accusative case, in Polish there are many examples with $w$ followed by a noun in the locative plural. In other words, the locative clearly represents the default case in the combination with $w$ in Polish temporal adverbials, whereas in East Slavic it is the accusative that functions as the default, as shown in in sections 3 through 5.

\begin{tabular}{|c|c|c|c|c|c|c|c|}
\hline & W+A Sg & $\mathrm{w}+\mathrm{APl}$ & $w+L$ Sg & $\mathrm{w}+\mathrm{LPl}$ & Bare G & other & Total \\
\hline sekunda 'second' & & & 1 & & & & 1 \\
\hline minuta 'minute' & & & & 1 & & & 1 \\
\hline moment 'moment' & & & 10 & 2 & & & 12 \\
\hline godzina 'hour' & & & 1 & 2 & & 20 & 23 \\
\hline pótnoc 'midnight' & & & & & & 1 & 1 \\
\hline południe 'noon' & & & 4 & & & & 4 \\
\hline ranek 'morning' & & & & & 1 & & 1 \\
\hline dzień 'day' & 3 & 5 & & 4 & 19 & 6 & 37 \\
\hline wieczór 'evening' & & 1 & & & 6 & 1 & 8 \\
\hline noc 'night' & 4 & 1 & 2 & & 8 & 1 & 16 \\
\hline tydzień 'week' & & & & & & 2 & 2 \\
\hline miesiac 'month' & & & 10 & & & & 10 \\
\hline lato 'Summer' & & & & & & & 0 \\
\hline rok 'year' & & & 7 & 2 & 1 & & 10 \\
\hline dekada 'decade' & & & 1 & & & & 1 \\
\hline stulecie 'century' & & & 1 & & & & 1 \\
\hline wiek 'age, century' & & & 4 & & & & 4 \\
\hline chwila 'time' & & & 19 & 1 & & 2 & 22 \\
\hline czas 'time' & & & 20 & 8 & 1 & 1 & 30 \\
\hline okres 'period' & & & 4 & & & & 4 \\
\hline pora 'time' & & & & & & 2 & 2 \\
\hline epoka 'epoch' & & & 1 & & & & 1 \\
\hline przyszłość 'future' & & & 3 & & & 1 & 4 \\
\hline
\end{tabular}




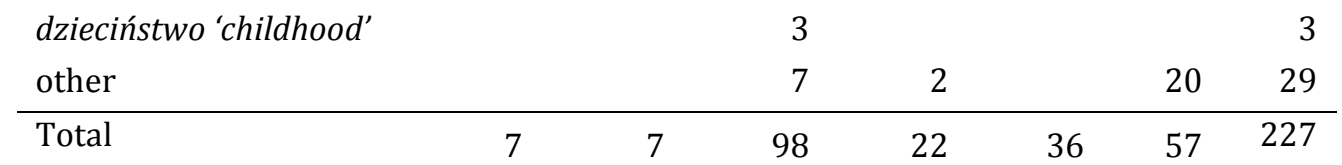

Table 4: The distribution of temporal adverbials in Polish

Although the locative dominates after $w$, we have some examples with the accusative. These examples concern days and parts of the day, where $w+$ accusative competes with the bare genitive. The examples with the bare genitive are more numerous, so we suggest that this is the local default for days and day parts. While we have seen that there is no plural effect in the choice between the accusative vs. the locative after $w$, there appears to be a restriction whereby the bare genitive does not combine with plural nouns in temporal adverbials. With day parts in the plural, therefore, $w+$ accusative is the preferred option:

(49) P: Jeszcze jedną próbę podjął w te zimowe dni. (Süskind)

'He poured it out the next day. He tried one more experiment during these winter days.'

The accusative also appears to be the preferred option when the temporal adverbial contains a postposed genitive modifier (cf. (50)) or a preposed adjectival modifier with a qualitative focus, such as in (51):

(50) P: Było tak jak w dzień narodzin Grenouille'a. (Süskind)

'It was a day like the one on which Grenouille was born.'

(51) P: Cuchnęła zabójczo kloaką, a jej wyziewy rozcieńczone świeżym powietrzem dawały efekt taki, jak gdyby stanąć w upalny letni dzień na rue aux Fers w Paryżu, przy rogu rue de la Lingerie, gdzie zderzały się wonie z Hal, Cmentarza Niewiniątek i zatłoczonych domów. (Süskind)

'Its stink was putrid, like a sewer, and if you fanned its vapor just once to mix it with fresh air, it was as if you were standing in Paris on a hot summer day, at the comer of the rue aux Fers and the rue de la Lingerie, where the odors from Les Halles, the Cimetiere des Innocents, and the overcrowded tenements converged.'

The bare genitive, on the other hand, combines with pronominal modifiers, especially:

(52) P: Jeszcze tego samego wieczoru wrócił do przytomności. (Lem)

'Already the same evening he regained consciousness.'

Our data material does not contain reliable examples with the seasons, but the following example (not from our database) indicates that the bare genitive is compatible with the seasons:

(53) P: Nie było tego lata tygodnia, żeby nie znaleziono zwłok jakiejś młodej dziewczyny. (Süskind)

'All that summer not a single week went by when the body of a young girl was not discovered.' 
In our database there is one example where the bare genitive is used for the noun rok 'year':

(54) P: W szopie w wysłanym watą pudełeczku spoczywały dwadzieścia cztery małe flakoniki ze skroploną aurą dwudziestu czterech dziewic najwspanialsze esencje, jakie Grenouille sporządził ubiegłego roku. (Süskind)

'Out in his cabin was a crate padded with cotton, in it were twenty-four tiny flacons filled with drops of the congealed aura of twenty-four virgins precious essences that Grenouille had produced over the last year.'

Summarizing our discussion of the bare genitive, we may say that the genitive shows an affinity to cyclic time spans (day parts and seasons), but also that it is attested for calendric notions such as 'year' and 'day' (as a reference to a date). In other words, there is arguably a cyclicity effect, but it is not strong since the genitive is not limited to cyclic time spans only. Furthermore, we have seen that the genitive combines with pronominal modifiers and is restricted to nouns in the singular.

Polish resembles Belarusian and Ukrainian in the use of the preposition $o$ followed by the locative case. Recall from the previous section that we have 9 examples with $a$ in Belarusian and 23 Ukrainian examples with the relevant preposition. Polish occupies an intermediate position, insofar as we have 17 attestations with $o+$ locative in our database. Like in Ukrainian, the vast majority of the examples (namely 14) involve godzina 'hour'.

The following generalizations sum up the situation in Polish:

(55) Generalizations for Polish:

a. Day (parts) in the plural $\rightarrow w+$ accusative

b. Day (parts) with postposed genitive or preposed qualitative modifier $\rightarrow w$ + accusative

c. Cyclic time spans elsewhere $\rightarrow$ bare genitive

d. Hour, midday, midnight $\rightarrow o+$ locative

e. Elsewhere $\rightarrow w+$ locative

Although the generalizations in (55) simplify the situation somewhat, they are sufficiently precise to clarify the differences between Polish and the East Slavic languages discussed in the preceding sections. First and foremost, the locative has a stronger position in Polish and is the default case after $w$, whereas in East Slavic the accusative is the default. Furthermore, (55) emphasizes the importance of the bare genitive in Polish, while the bare instrumental is not attested in our database.

Despite the differences between Polish and the East Slavic languages, Polish resembles East Slavic with regard to space-time asymmetries. In the domain of space, the Polish preposition $w$ governs the accusative with directed motion, but takes the locative in situations where something is located inside a three-dimensional space (Bielec 1998, 224-225; Sadowska 2012, 58-72, 88-92). However, it is worth pointing out that $w+$ accusative appears to be less widely used in spatial constructions in Polish than in East Slavic, since in Polish do + genitive is the "most popular preposition for expressing movement to a goal" 
(Sadowska 2012, 538, see also Bielec 1998, 216, Swan 2002, 342 and Janda 2002). Although $w+$ accusative is not the preferred option in spatial constructions in Polish, the accusative is attested in examples such as ide $w$ gory 'I'm going to the mountains' (Sadowska 2012, 538), so the use of the accusative vs. the locative cases after $w$ is contrastive in Polish spatial constructions. In the domain of time, on the other hand, the two cases are in complementary distribution, in the sense that the choice of case is predictable from the meaning of the governed noun phrase, as shown in (55). Since the opposition between spatial direction/movement vs. location is weakened in Polish, Polish offers less strong evidence in favor of the Constraint Hypothesis than the East Slavic data. However, at the same time the Polish data do not contradict the hypothesis either, since the spatial opposition is not quite neutralized.

\section{Czech}

We have now come to the westernmost language in our sample, Czech, which as we will show has a system of temporal adverbials that is close to the Polish system discussed above. In Czech, like in Polish, the default case after $v$ 'in(to)' is the locative in temporal adverbials, and we do not observe the sensitivity to extendedness and boundedness that is characteristic of East Slavic. However, the Czech and Polish systems are not identical. Notably, we find examples of the bare accusative in Czech, but not in our Polish data, while the use of the preposition $o$ is more widespread in Polish than in Czech.

Table 5 shows that in Czech, like in Polish, the locative dominates after $v$ 'in(to)' in temporal adverbials, so the locative appears to be the default case in such constructions. This applies regardless of number; we observe no plural effect in our Czech data. The only noun for which $v+$ accusative is the most frequent construction in our dataset is hodina 'hour':

(56) Cz: V devět hodin palubního času jsem prošel kolem lidí stojících u startovací šachty. (Lem)

'At seven sharp local time I passed those who gathered around the lock chamber.'

As can be seen from the table, there are also some examples with hodina where $v$ combines with the locative plural:

(57) Cz: Věděl, co se odehraje v nejbližších hodinách: totiž v krámě vůbec nic a nahoře v Baldiniho pracovně obvyklá katastrofa. (Süskind)

'He knew what would happen in the next few hours: absolutely nothing in the shop, and up in Baldini's study, the usual catastrophe.'

However, in examples of this type we are not dealing with exact location in time. Instead, phrases like $v$ nejbližších hodinách 'in the nearest hours to come' are roughly equivalent to 'in a short while', 'soon' etc. It is not unexpected to find the 
locative in such examples, since, as shown in the table, Czech uses the locative for unbounded time spans. ${ }^{11}$

\begin{tabular}{|c|c|c|c|c|c|c|c|c|}
\hline & $\mathrm{V}+\mathrm{A} \mathrm{Sg}$ & $\mathrm{V}+\mathrm{A} \mathrm{Pl}$ & $V+L S g$ & $\mathrm{~V}+\mathrm{LPl}$ & Bare G & Bare A & Other & Total \\
\hline okamžik & & & 20 & 3 & & & 4 & 27 \\
\hline 'instant' & & & & & & & & \\
\hline $\begin{array}{l}\text { vteřina } \\
\text { 'second' }\end{array}$ & & & 1 & & & 1 & & 2 \\
\hline $\begin{array}{l}\text { hodina } \\
\text { 'hour' }\end{array}$ & 15 & 1 & & 4 & & & 3 & 23 \\
\hline $\begin{array}{l}\text { poledne } \\
\text { 'noon' }\end{array}$ & & & 2 & & & & 1 & 3 \\
\hline $\begin{array}{l}\text { půlnoc } \\
\text { 'midnight' }\end{array}$ & & & 1 & & & & & 1 \\
\hline $\begin{array}{l}\text { ráno } \\
\text { 'morning' }\end{array}$ & & & & & 1 & & & 1 \\
\hline den 'day' & 2 & 2 & & 6 & 15 & 7 & 3 & 35 \\
\hline $\begin{array}{l}\text { večer } \\
\text { 'evening' }\end{array}$ & & & & & 5 & 2 & 1 & 8 \\
\hline noc 'night' & & & 6 & & 6 & 1 & 2 & 15 \\
\hline $\begin{array}{l}\text { týden } \\
\text { 'week' }\end{array}$ & & & 1 & 1 & & & 1 & 3 \\
\hline $\begin{array}{l}\text { měsíc } \\
\text { 'month' }\end{array}$ & & & 12 & & & & & 12 \\
\hline rok 'year' & & & 8 & 4 & 2 & & & 14 \\
\hline $\begin{array}{l}\text { desetiletí } \\
\text { 'decade' }\end{array}$ & & & 1 & & & & & 1 \\
\hline $\begin{array}{l}\text { století } \\
\text { 'century' }\end{array}$ & & & 3 & & & & & 3 \\
\hline $\begin{array}{l}\text { mládí } \\
\text { 'youth' }\end{array}$ & & & 2 & & & & & 2 \\
\hline $\begin{array}{l}\text { stář́i } \\
\text { age' }\end{array}$ & & & 1 & & & & & 1 \\
\hline $\begin{array}{l}\text { budoucnost } \\
\text { 'future' }\end{array}$ & & & 1 & & & & 1 & 2 \\
\hline $\begin{array}{l}\text { období } \\
\text { 'period' }\end{array}$ & & & 3 & & & & & 3 \\
\hline $\begin{array}{l}\text { chvíle } \\
\text { 'while' }\end{array}$ & & & 4 & & & & & 4 \\
\hline čas 'time' & & & 1 & 3 & & & & 4 \\
\hline $\begin{array}{l}\text { doba } \\
\text { 'period' }\end{array}$ & 3 & & 13 & 3 & & & 2 & 21 \\
\hline other & & & 5 & & & & 31 & 36 \\
\hline Total & 20 & 3 & 85 & 24 & 29 & 11 & 49 & 221 \\
\hline
\end{tabular}

Table 5: The distribution of temporal adverbials in Czech

As shown in the table, we have 29 examples with the bare genitive. In our data material the majority of these examples concern den 'day' and parts of the day cycle (rano 'morning', večer 'evening' and noc 'night'):

\footnotetext{
${ }^{11}$ As pointed out by an anonymous referee, $o+$ accusative is also possible in Czech temporal adverbials. However, since $o+$ accusative was not attested in our database, a discussion of this construction is beyond the scope of the present article.
} 
(58) Cz: Nešt'astnou shodou okolností bylo toho dne, asi hodinu poté, co vyrazily průzkumné skupiny, přerušeno rádiové spojení. (Lem)

'As misfortune would have it, on that day, an hour after the departure of the reconnaissance group, the radio connection was interrupted.'

(59) Cz: Hned prvního večera musel Grenouille namíchat velký balón Nuit Napolitaine. (Süskind)

'The very first evening, Grenouille had to prepare a large demijohn full of Nuit Napolitaine.'

Examples with the day parts like (59) suggest a cyclicity effect, whereby cyclic time spans are used in different constructions compared to non-cyclic nouns. This is confirmed in searches in the Czech National Corpus, which show that the bare genitive is used not only with the day cycle, but also with the cycle of seasons: ${ }^{12}$

(60) Cz: Toho jara Brno skutečně zachránilo Osvobozené divadlo.

'That spring Brno really saved the Liberated Theater.'

While the use of the bare genitive resembles Polish, Czech is different insofar as the bare genitive competes with the bare accusative, a construction that is not attested in our Polish material. The Czech bare accusative appears to be used less frequently, but seems to occur in approximately the same contexts as the bare genitive. However, in the same way as in Polish, the bare genitive seems to be incompatible with nouns in the plural. No such restriction holds for the bare accusative:

(61) Cz: Žuchraj tyto dny neznal klidu. (Ostrovskij)

'Those days Žuchraj had no peace.'

In the previous sections we have seen that Belarusian, Ukrainian and Polish use the preposition $o$ ( $a$ in Belarusian) followed by the locative in temporal adverbials. In our Czech material, we have only one example with this construction, suggesting that it is peripheral in Czech:

(62) Cz: Venku byla neurčitá denní doba, většinou začínající nebo končící noc, ale dokonce i o půlnoci ho do očí bodal jas hvězdné záře jako jehly. (Süskind)

'Outside it would be some time of day or another, usually toward the beginning or end of night; but even at midnight, the brightness of the starlight pricked his eyes like needles.'

\footnotetext{
12 The Czech National Corpus is available at http://ucnk.ff.cuni.cz. Corpus searches were performed in May 2012. Notice that although the bare instrumental was not attested in our database and we were not able to find it in the Czech National Corpus, the bare instrumental appears to be marginally possible in Czech, as shown by the following example from a google search:
}

(i) To budu spíš tou zimou venku.

'It's more likely that I will be outside this winter.' 
We are now in a position to summarize the Czech system. As shown in (63), the Czech system is close to the Polish, but the two systems are not identical:

(63) Generalizations for Czech:

a. hodina 'hour' $\rightarrow v+$ accusative

b. den 'day' $\rightarrow$ ( $v+$ accusative $)$ or bare genitive (or bare accusative)

c. Cyclic time spans $\rightarrow$ bare genitive (or bare accusative)

d. Elsewhere $\rightarrow v+$ locative

In the previous sections, we have seen that all the languages under scrutiny display space-time asymmetries. While in time the accusative and locative cases are in complementary distribution, in space the two cases are contrastive insofar as the accusative signals movement or direction, whereas the locative is a marker of location within a three-dimensional space. Czech resembles Polish. In the domain of time, we have complementary distribution, as shown in (63), whereas the "use of $v+$ accusative [...] to indicate physical movement in space is very limited, generally encountered only in fixed expressions, like bít se v prsa [beat self-ACC in chest-ACC] 'beat one's chest' (where the chest is the destination of the beating)" (Janda and Clancy 2006, 124). This suggests that the spatial direction/movement vs. location opposition does exist in Czech, but that it is much weaker than in the East Slavic languages, and possibly even Polish. Accordingly, the relationship between space and time in Czech is less asymmetrical - in fact, Czech approaches symmetry between spatial and temporal constructions. In view of this, Czech offers less strong evidence in favor of the Constraint Hypothesis introduced in section 2. However, at the same time the Czech data are not at variance with the hypothesis either, insofar as the spatial direction/movement vs. location opposition is not quite neutralized.

\section{Statistical analysis: a North Slavic continuum}

On the basis of the languages analyzed in sections 3 through 7 we propose a North Slavic Temporal Adverbial Continuum. We have seen that in East Slavic the accusative is the default after the prepositions meaning 'in', while the locative serves as the default in the corresponding West Slavic constructions. However, we have identified a number of transitional phenomena involving other prepositions and the use of bare cases, which suggest that we are dealing with a continuum, rather than a strict boundary between East and West Slavic. In the following we argue that the hypothesis of the North Slavic Temporal Adverbial Continuum receives further empirical support from two statistical tests, namely principal components analysis and linear regression.

The data are summarized in Table 6, which shows the five languages from west to east along the horizontal axis and the relevant constructions along the vertical axis. The number in a given cell represents the number of attested examples with a given construction in a given language. In addition to the constructions with $v+$ accusative or locative, the constructions fall into three main types: constructions with other prepositions, constructions with bare cases (i.e. noun phrases not governed by a preposition), and adverbs. 


\begin{tabular}{lrrrrr} 
& Czech & Polish & Ukrainian & Belarusian & Russian \\
\hline$V+$ accusative & 23 & 14 & 96 & 152 & 232 \\
$V+$ locative & 108 & 120 & 22 & 33 & 39 \\
Bare accusative & 11 & 0 & 1 & 3 & 0 \\
Bare genitive & 29 & 36 & 40 & 9 & 0 \\
Bare instrumental & 0 & 0 & 7 & 12 & 0 \\
Other P + accusative & 7 & 3 & 4 & 9 & 0 \\
Other P + dative & 0 & 1 & 0 & 0 & 0 \\
Other P + genitive & 24 & 30 & 34 & 13 & 0 \\
Other P + instrumenal & 0 & 0 & 1 & 4 & 0 \\
Other P + locative & 19 & 23 & 25 & 9 & 0 \\
Adverb & 22 & 15 & 20 & 9 & 0 \\
Other constructions & 26 & 27 & 21 & 12 & 0 \\
Not attested & 2 & 2 & 0 & 6 & 0 \\
\hline Total & 271 & 271 & 271 & 271 & 271 \\
Table 6: Equivalents of Russian $\boldsymbol{v}+$ accusative or locative in North Slavic &
\end{tabular}

Before we turn to the analysis of the data in Table 6 , one point deserves mention. In the column for Russian, there are zero values for all constructions except $v+$ accusative and $v+$ locative. This does not mean that all of the remaining constructions are impossible in Russian. Rather, this fact is a consequence of the methodology we chose. Since we searched for equivalents of the Russian $B(0)+$ accusative/locative constructions, no other constructions could in principle be obtained for Russian. However, as the reader may recall, we have discussed alternative constructions in Russian in the text in section 3.

Let us start by comparing the numbers for the accusative and locative after the preposition meaning 'in' in the five languages. Table 7 provides the percentages of these constructions and other relevant constructions for the languages in question, i.e. the proportions of the 271 example sentences for each construction in each language. The table shows that the accusative is the dominant case after $v$ in Russian and Belarusian, while Czech and Polish display this construction in less than $10 \%$ of the attested examples. Conversely, Czech and Polish show high percentages for 'in' + locative (about 40\%), whereas Belarusian and Russian have fairly low percentages (between $12 \%$ and 15\%). Ukrainian occupies an intermediate position between the East and West Slavic languages under scrutiny. With regard to 'in' + accusative, Ukrainian shows 35\%, which is in between the low $(<10 \%)$ for Czech and Polish on the one hand, and the high ( $>50 \%$ ) for Belarusian and Russian on the other. At the same time, Ukrainian resembles the West Slavic languages, insofar as Ukrainian has other constructions than $v+$ accusative/locative in more than $50 \%$ of the examples attested in our database.

\begin{tabular}{lrrrrr} 
& Czech & Polish & Ukrainian & Belarusian & Russian \\
\hline$V+$ accusative & $8.5 \%$ & $5.2 \%$ & $35.4 \%$ & $56.1 \%$ & $85.6 \%$ \\
$V+$ locative & $39.5 \%$ & $44.3 \%$ & $8.1 \%$ & $12.2 \%$ & $14.4 \%$ \\
$O+$ locative & $0.4 \%$ & $6.3 \%$ & $8.5 \%$ & $3.3 \%$ & $0 \%$ \\
Bare genitive & $10.7 \%$ & $13.3 \%$ & $14.7 \%$ & $3.3 \%$ & $0 \%$
\end{tabular}




$\begin{array}{lrrrrr}\text { Bare accusative } & 4 \% & 0 \% & 0.4 \% & 1.1 \% & 0 \% \\ \text { Bare instrumental } & 0 \% & 0 \% & 2.6 \% & 4.4 \% & 0 \% \\ \text { Other constructions } & 36.9 \% & 30.9 \% & 30.3 \% & 19.6 \% & 0 \% \\ \text { Total } & 100 \% & 100 \% & 100 \% & 100 \% & 100 \%\end{array}$

Table 7: Distribution of $v+$ accusative/locative in percent

On the basis of the data exposed in Table 7, we propose that the languages under scrutiny form a continuum with regard to the 'in' + accusative/locative constructions. Rather than a clear-cut distinction between the languages of the West and East Slavic groups, we observe a gradual transition from east to west, whereby Ukrainian represents a transitional state of affairs. In fact, although genetically speaking Ukrainian belongs to the East Slavic group, Ukrainian behaves like the West Slavic languages in some respects, notably with regard to the distribution of "other constructions". ${ }^{13}$

In order to test our hypothesis, we carried out a principal components analysis of the data in Table 6 by means of the statistical software package $R$ (2011). We wanted to find out if there is a relationship between the choice of construction and the geographical distribution of the languages along the eastwest axis. In more precise terms, the task we gave the statistical model was to predict the language from the use of the relevant constructions. In order for the model to be able to solve this task, it was necessary to assign measurable geographical coordinates to the languages. For this purpose, for each language we factored the latitude and longitude of the relevant capital city into the principal components analysis. However, since Ukrainian is much stronger in Western Ukraine, we used the coordinates of the city of Lviv rather than Kiev as the geographical reference point for Ukrainian. In other words, the languages were identified with the latitudes and longitudes of the following cities: Prague (Czech), Warsaw (Polish), Lviv (Ukrainian), Minsk (Belarusian) and Moscow (Russian). Furthermore, the relevant cities represent large population centers for the languages in question, and thus give a reasonably good indication of where the languages are spoken in Europe.

The principal components analysis gave the plot in Figure 1. The model takes into account the 12 variables presented in Figure 1 and reduces the dimensionality to two dimensions, which jointly account for $79 \%$ of the variance. These factors are referred to as "P(rincipal) C(omponent) 1" and "P(rincipal) C(omponent) 2". PC1, which is the dimension accounting for most of the variance, occupies the horizontal axis, while PC2 occupies the vertical dimension. In Figure 1, we see that the two dimensions roughly correspond to geographical space. The horizontal dimension (PC1) groups the languages along the east-west axis, although the west is to the right and the east to the left; Russian and Belarusian are placed to the left and Polish and Czech to the right, while Ukrainian occupies an intermediate position. The vertical axis (PC2) roughly corresponds to the north-south dimension, insofar as Russian and Polish are placed in the upper portion of the panel and Belarusian, Ukrainian and Czech further down. The constructions are represented as vectors (arrows) starting in

\footnotetext{
${ }^{13}$ Admittedly, the category "other constructions" is heterogeneous, but our database is not large enough to permit statistically reliable analysis based on a more fine-grained classification.
} 
the middle of the figure (the origin of the system of coordinates) and pointing at the parts of the geographical space, for which they are most characteristic. For our purposes, two vectors are of particular interest. The vector marked "vacc" represents the $v+$ accusative construction. As can be seen from Figure 1, it is characteristic for Russian and Belarusian, i.e. the easternmost languages in our sample - as predicted by the North Slavic Temporal Adverbial Continuum Hypothesis. The vector "vloc", which represents the $v+$ locative construction, points in the opposite direction, thus stating that this construction is characteristic of the western languages, viz. Polish and Czech. Again, this is as predicted by the North Slavic Temporal Adverbial Continuum Hypothesis. To summarize, therefore, the principal components analysis lends support to our hypothesis.

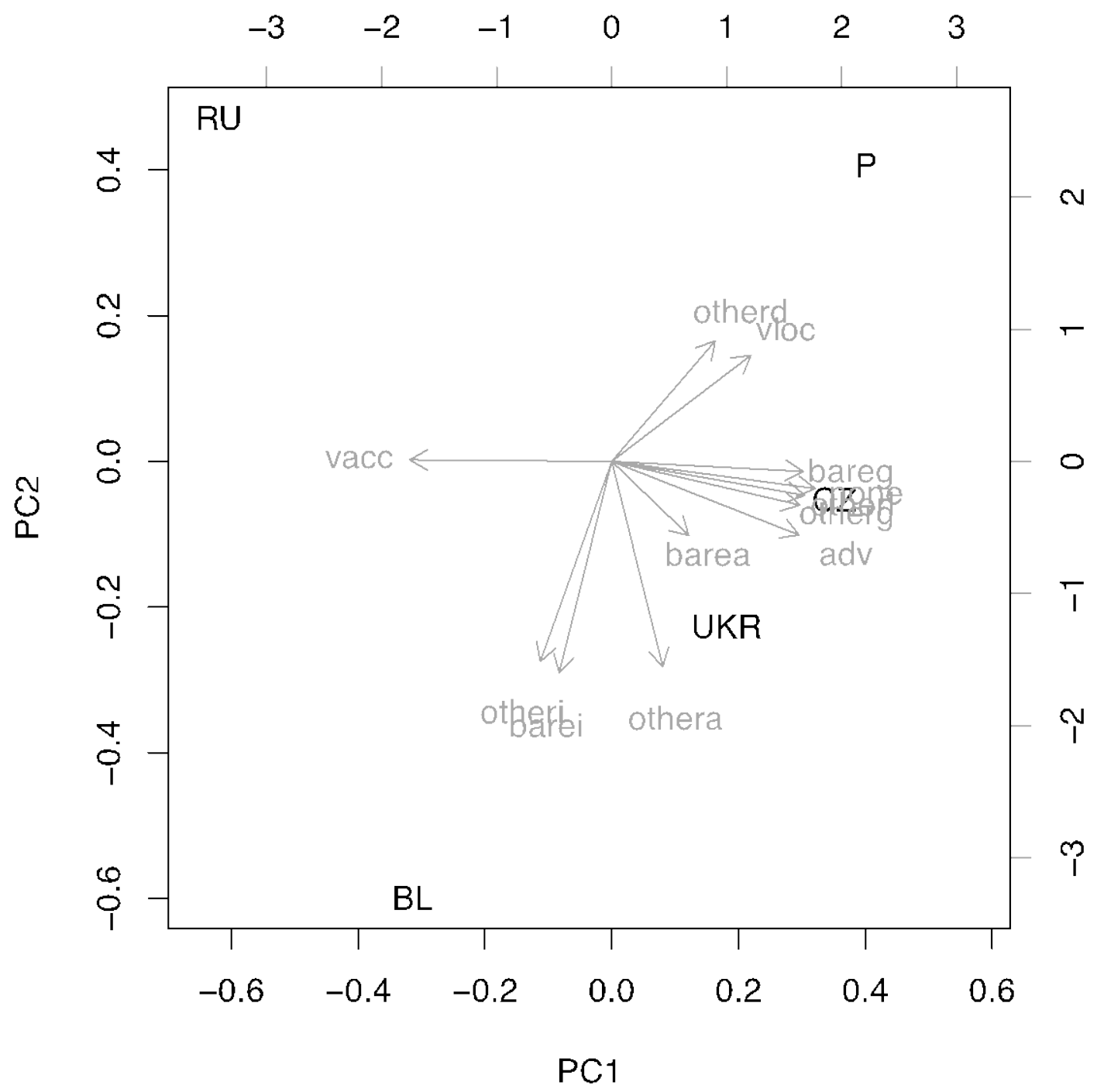

Figure 1: Plot from principal components analysis. Abbreviated names of constructions: vacc $=v+$ accusative, vloc $=v+$ locative, barea=bare accusative, bareg=bare genitive, barei=bare instrumental, othera=other preposition + the accusative, otherd=other preposition + the dative, otherg=other preposition + the genitive, otheri=other 
preposition + the instrumental, oherl=other preposition + the locative, $a d v=a d v e r b$, and none=no temporal adverbial.

As an additional test of our hypothesis, we applied a linear regression model to the data in Table 6 . The task the model was given was to predict the choice of construction from geographical longitude. The model is summarized by the plot in Figure 2. As shown in the figure, the languages constitute a nearly straight line from the upper left to the lower right $(r=-0.91, t=-3.936, d f=3, p-$ value $=0.02922$ ). This shows that we are dealing with an almost perfect linear functional relation between the two factors - geographical longitude and choice of construction (named "PC1" in the figure). Since this shows that there is indeed a strong relationship between longitude and the choice of construction, the linear regression test lends additional support to the North Slavic Temporal Adverbial Continuum Hypothesis.

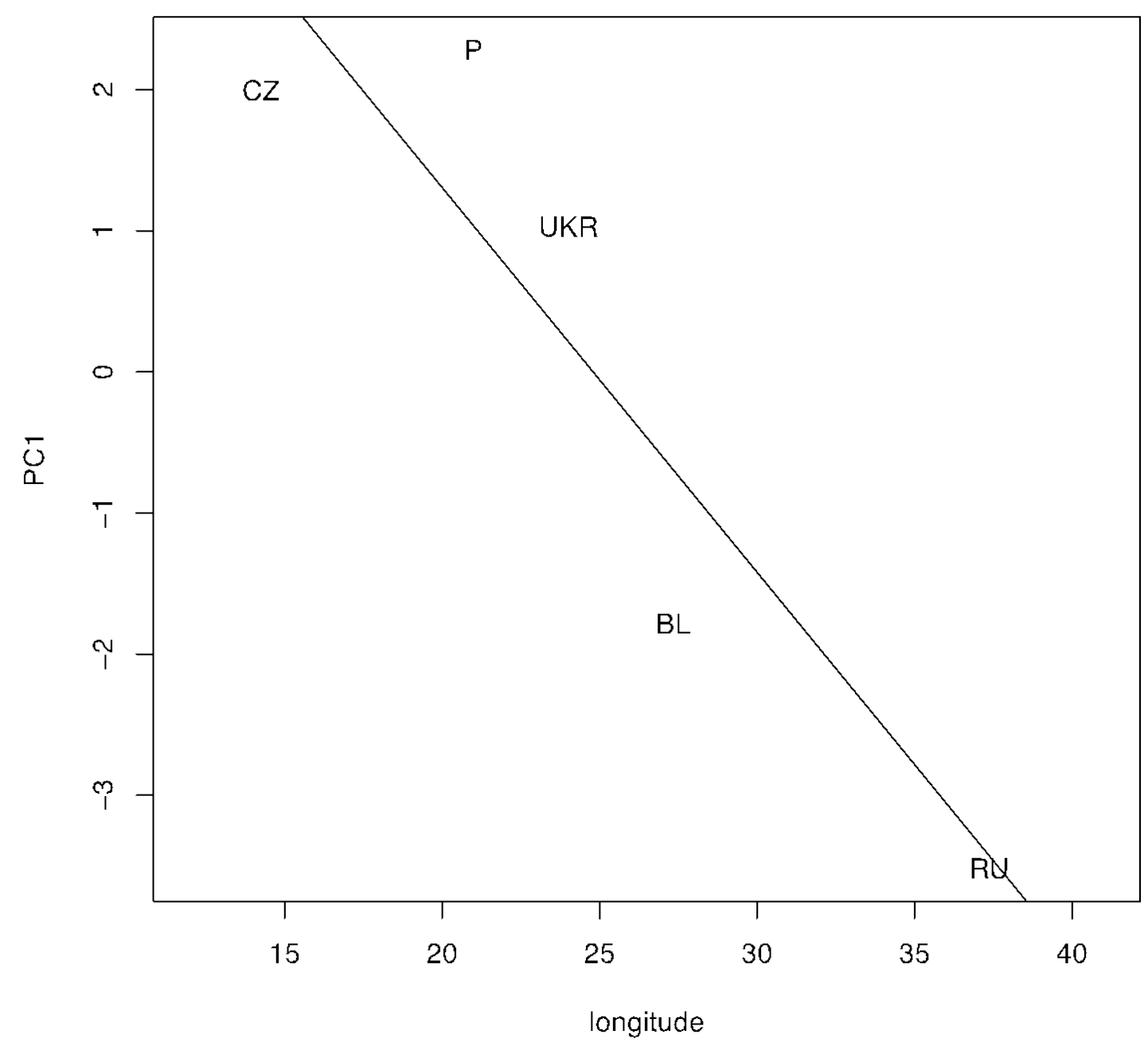

Figure 2: Scatterplot from linear regression analysis of the relationship between geographical longitude and choice of construction.

Summarizing this section we have seen that our hypothesis about the North Slavic Temporal Adverbial Continuum receives support from the statistical models we have described above. Both the principal components and linear 
regression analyses have explicated and visualized the relationships between the five languages under scrutiny in the present study.

\section{Concluding discussion}

In this article we have tested two hypotheses against data from the ParaSol corpus combining qualitative analysis with the use of statistical methods. Our hypothesis about the North Slavic Temporal Adverbial Continuum involves a gradual transition from the east to the west when it comes to temporal adverbials. Table 8, where the languages are allocated according to geographical longitude, summarizes the situation. The table is organized in three portions separated by dashed lines. The upper portion indicates the default case after 'in'; we see that the locative is the default in West Slavic, while East Slavic has the accusative as the default.

The middle portion of the table concerns the effects of the pluralization, cyclicity and modifiers, where a "+" indicates the presence of an effect, while a "" represents no such effect. The plural effect, which we find in East Slavic, is that the accusative is preferred with nouns in the plural, although the singular forms of the nouns in question prefer the locative. The cyclic effect, which is attested in all five languages, is that nouns describing parts of the natural cycles of the day and the seasons have different constructions than nouns denoting calendric time spans. In our database, we have encountered the modifier effect in all languages except Czech. This means that the presence of preposed or postposed modifiers has an impact on the choice of construction in temporal adverbials.

The lower portion of Table 8 describes the three most widely attested alternative constructions, namely the bare genitive and instrumental cases, as well as the preposition $o$ (and its cognates) followed by the locative. Again, "+" means that the relevant construction is attested, while "-" indicates its absence. For constructions that appear to be marginal, we include "-" in parentheses. Shaded table cells represent a construction's "center of gravity", i.e. the language(s) where it is most widely attested. While the bare instrumental gravitates to the east, the bare genitive and the $o$ + locative constructions have their centers of gravity in Polish and Ukrainian, i.e. in the central part of the North Slavic area.

While the defaults after 'in' are different in East and West Slavic, the three effects and the three alternative constructions do not indicate a clear-cut division line between East and West Slavic. We conclude that the most precise model of the situation is a continuum. As shown in section 8, the North Slavic Temporal Adverbial Continuum receives support from statistical analysis (principal components analysis and linear regression).

\begin{tabular}{lccccc} 
& Czech & Polish & Ukrainian & Belarusian & Russian \\
\hline Default after 'in' & Loc & Loc & Acc & Acc & Acc \\
\hline Plural effect & - & - & + & + & + \\
Cyclic effect & + & + & + & + & + \\
Modifier effect & - & + & + & + & + \\
\hline Bare genitive & + & + & + & + & - \\
Bare instrumental & - & - & + & + & +
\end{tabular}


The continuum we propose has implications for future research in Slavic linguistics. First, it remains to be seen whether other constructions involving the category of case adhere to the continuum. Second, an important question is to what extent other grammatical categories display similar behavior. Of particular interest is the category of aspect, since Dickey (2001) has divided the Slavic languages into two aspectual groups, a western and an eastern group, in addition to a transitional zone between the two. Since both aspect and temporal adverbials reflect the conceptualization of time, one must ask whether there is a conceptual link between Dickey's grouping and the continuum we propose. However, this question is beyond the scope of the present study and must be left open for future research (but see Nesset under submission for brief discussion).

The second hypothesis under scrutiny in this article is the Constraint Hypothesis, according to which case government is more constrained in the domain of time than in the domain of space. Our analysis of the five North Slavic languages has provided ample empirical support for the Constraint Hypothesis. Even though the five languages display different systems of temporal adverbials, in the domain of time the accusative and locative cases are in complementary distribution in all of them. In the domain of space, on the other hand, the distribution of the cases is contrastive, insofar as the accusative indicates direction or movement, whereas the locative is used about stative location within a three-dimensional space. Since we have contrastive distribution in the domain of space, but not in the temporal domain, the predictions of the Constraint Hypothesis are borne out by the facts explored in this article.

Our discussion of the Constraint Hypothesis indicates that the domains of space and time are not entirely parallel - we are dealing with a set of space-time asymmetries. Although we do not deny that there is a metaphorical mapping relationship between the domains of time and space, our research suggests that once these mappings have been established, temporal constructions may take on a life on their own and develop their own properties, as predicted by Fauconnier and Turner (2008), who describe time as an emergent property in a complex network of blended mental spaces. The study of space-time asymmetries represent a promising alley for future research with implications beyond Slavic languages, since they shed light on the relationships between concrete and abstract domains - a topic of major importance not only in cognitive linguistics, but also in cognitive science in general.

\section{References}

Baayen, R. H., S. M. Dickey, A. Endresen, L. A. Janda, A. Makarova and T. Nesset: This volume. Making choices in Slavic: Pros and cons of statistical methods for rival forms, Russian Linguistics VOLUME: PAGE RANGE TO BE ADDED.

Bielec, D.: 1998. Polish: An Essential Grammar, London and New York.

Bulaxovskij, L. A.: 1954. Russkij literaturnyj jazyk pervoj poloviny XIX veka, Moscow. 
Dahl, Ö.: To appear. How Telicity Creates Time, Journal of Slavic Linguistics VOLUME: PAGE RANGE TO BE ADDED.

Endresen, A.: This volume. Spatial Sources of Temporal Approximation: The Russian prepositions O(B) and OKOLO 'about, around', Russian Linguistics VOLUME: PAGE RANGE TO BE ADDED.

Fauconnier, G. and M. Turner: 2008. Rethinking metaphor. In R. W. Gibbs (ed.): The Cambridge Handbook of Metaphor and Thought (pp. 53-66). Cambridge.

Grannes, A.: 1986. "Genitivus Temporis" in Early 18th Century Russian. Russian Linguistics 10.1: 53-60.

Haspelmath, M.: 1997. From space to time: temporal adverbials in the world's languages, Munich.

Isačenko, A. I.: 1984. Die russische Sprache der Gegenwart: Formenlehre, Munich.

Janda, L. A.: 2002. The Case for Competing Conceptual Systems. In B. Lewandowska-Tomaszczyk and K. Turewicz (eds.): Cognitive Linguistics Today (pp. 355-374). Frankfurt.

Janda, L. A. and S. J. Clancy: 2002. The Case Book for Russian, Bloomington IN.

Janda, L. A. and S. J. Clancy: 2006. The Case Book for Czech, Bloomington IN.

Klein, W.: 1994. Time in Language, London and New York.

Klein, W.: 2009. How time is encoded. In W. Klein and Ping Li (Eds.), The Expression of Time (pp. 39-82). Berlin and New York.

Kuznetsova, J., V. Plungian and E. Rakhilina: This volume. Time as a side-effect of space: Russian pod 'under' and iz-pod 'from-under' in temporal constructions, Russian Linguistics VOLUME: PAGE RANGE TO BE ADDED.

Lakoff, G.: 1993. The contemporary theory of metaphor. In A. Ortony (Ed.), Metaphor and Thought (pp. 202-251). Cambridge.

Lakoff, G. and M. Johnson: 1980. Metaphors we live by, Chicago.

Langacker, R. W.: 2009: Metonymic grammar. In K. U. Panther, L. Thornburg and A. Barcelona (Eds.): Metonymy and Metaphor in Grammar, Amsterdam and Philadelphia.

Lomtev, T. P.: 1956. Grammatika belorusskogo jazyka, Moscow.

Nesset, T.: 2004. Case assignment and image schemas: Russian temporal adverbials, Studies in Language 28.2: 285-319.

Nesset, T.: 2008. Abstract Phonology in a Concrete Model. Cognitive Linguistics and the Morphology-Phonology Interface, Berlin and New York.

Nesset, T.: 2011. Space-Time Asymmetries in Russian Prepositions: Preliminary Analysis, Poljarnyj Vestnik 14: 45-62.

Nesset, T.: under submission. How Russian became Typologically Unusual: the History of Russian Temporal Adverbials with $v$ 'in(to)'. Manuscript, University of Tromsø.

Plungian, V. and E. Rakhilina: This volume. Time and Speed: Where do Speed Adjectives Come From?, Russian Linguistics VOLUME: PAGE RANGE TO BE ADDED.

R Development Core Team: 2011. R: A language and environment for statistical computing. R Foundation for Statistical Computing, Vienna, Austria. ISBN

3-900051-07-0, URL http://www.R-project.org/

Rubinstein, G. A.: 2001. Asimmetrija sintaksičeskix svojstv russkix nazvanij častej sutok. Glossos 1: 1-18.

Sadowska, I.: 2012. Polish: A Comprehensive Grammar, London and New York. 
Swan, O. E.: 2002, A grammar of contemporary Polish, Bloomington IN. Švedova, N. Ju. (Ed.): 1980. Russkaja grammatika (vol. 2), Moscow.

Vyxovanec', I. and K. Gorodens'ka: 2004. Teoretična morfologija ukraïns'koï movy, Kyïv. 